\title{
Meta-analysis of the immunocastration technique (anti-GnRH) for male bovines in the finishing phase
}

\author{
Diego Soares Machado(1), Guilherme Joner(2), Lucas Braido Pereira(1), \\ Luciana Pötter ${ }^{(1)}$, Ivan Luiz Brondani ${ }^{(1)}$ and Dari Celestino Alves Filho(1)
}

\begin{abstract}
(1)Universidade Federal de Santa Maria, Departamento de Zootecnia, Avenida Roraima, № 1.000, Cidade Universitária, Camobi, CEP 97105900 Santa Maria, RS, Brazil. E-mail: dsm_zootecnista@hotmail.com, braidopereira@gmail.com, luciana.forragicultura.ufsm@gmail.com, brondani@pesquisador.cnpq.br, darialvesfilho@hotmail.com (2)Universidade Federal do Pampa, Campus Dom Pedrito, Rua 21 de Abril, no 80, São Gregório, CEP 96450-000 Dom Pedrito, RS, Brazil. E-mail: guilhermejoner@unipampa.edu.br
\end{abstract}

\begin{abstract}
The objective of this work was to analyze the effects of immunocastration on the performance and carcass quality of steers in the finishing phase, compared with non-castration and surgical castration. Data from ten studies with records of 1,261 male bovines were analyzed. The studies included in the meta-analysis necessarily contained treatments with immunocastration specifically against the gonadotropin-releasing hormone. Each study was considered as a random effect in the statistical model used. The data were tested for homogeneity of variances and residue normality, and then subjected to the analysis of variance. Means were compared by Student's t-test. Non-castrated steers showed greater daily weight gain, feed efficiency, slaughter and hot carcass weights, and loin eye area, besides lower fat thickness than surgically-castrated animals and the lowest $\mathrm{a}^{*}$ and $\mathrm{b}^{*}$ meat coloration values. Overall, immunocastrated steers were inferior to the non-castrated ones, but superior to those surgically-castrated. Immunocastrated steers present performance and carcass traits superior to those of surgically-castrated animals, but similar meat quality.
\end{abstract}

Index terms: castration methods, daily weight gain, fat cover, forest plot, meat quality.

\section{Meta-análise da técnica de imunocastração (anti-GnRH) para bovinos machos em fase de terminação}

\begin{abstract}
Resumo - O objetivo deste trabalho foi analisar os efeitos da imunocastração sobre o desempenho e a qualidade de carcaça de novilhos em terminação, em comparação à não castração e à castração cirúrgica. Analisaram-se dados de dez estudos, com registros de 1.261 bovinos machos. Os estudos incluídos na meta-análise continham, necessariamente, tratamentos com imunização ativa contra o hormônio liberador de gonadotrofinas. Cada estudo foi considerado como efeito aleatório no modelo estatístico utilizado. Os dados foram testados quanto à homogeneidade de variâncias e à normalidade dos resíduos, e, posteriormente, submetidos à análise de variância. As médias foram comparadas pelo teste $t$ de Student. Os novilhos não castrados apresentaram maiores ganho de peso diário, eficiência alimentar, pesos ao abate e de carcaça quente, e área de olho de lombo, além de menor espessura de gordura que os castrados cirurgicamente e menores valores de $\mathrm{a}^{*} \mathrm{e}$ $\mathrm{b}^{*}$, para coloração da carne. No geral, os novilhos imunocastrados foram inferiores aos não castrados, mas superiores aos castrados cirurgicamente. Novilhos submetidos à imunocastração apresentam características de desempenho e de carcaça superiores aos castrados cirurgicamente, mas qualidade de carne similar.
\end{abstract}

Termos para indexação: métodos de castração, ganho de peso diário, gordura de cobertura, forest plot, qualidade de carne.

\section{Introduction}

The surgical castration of production animals is a common, but controversial practice, which is often carried out to reduce problems related to aggression and sexual behavior (Price et al., 2003). According to Freitas et al. (2008), this procedure may also influence the meat quality of steers, since it increases carcass fat thickness, which is a trait desired by the industry in order to protect the carcass during refrigeration, avoiding undesirable visual appearance and a phenomenon known as "cold shortening" of meat.

However, many producers prefer not to castrate male bovines marked for finishing. This is to take advantage of the anabolic hormone (testosterone), which promotes muscle hypertrophy and results in greater weight gain, slaughter and carcass weights, as 
well as carcass and muscle yields (Moletta et al., 2014). In addition, this type of procedure is also negatively perceived due to the distress inflicted to the animals (Coetzee et al., 2010). According to Grandin (2014), castration and dehorning are the main causes of pain and suffering of bovines reared wholly or partially with free animals in the pasture, and may also result in costs related to postoperative complications, lower weight gains, and increased risk of death.

In this context, the production and commercialization of beef has been undergoing a transformation in the last years, with animal welfare concepts becoming one of the pillars that support current production systems. Therefore, other castration strategies have been developed, taking into account the welfare of both animals and the people involved in management activities, with less stress and greater safety for both.

Immunocastration represents a sound alternative to the surgical procedure. The technique reduces the production of testicular steroids (Oliver et al., 2003) by immunizing against the gonadotropin-releasing hormone (GnRH) (Janett et al., 2012a). This interrupts the hypothalamic-pituitary-gonadal axis by hindering the access of secreted GnRH to its action site in the pituitary gland. This way, regardless of the adopted castration method, the pituitary is not able to release the luteinizing and follicle-stimulating hormones that promote testosterone synthesis in male gonads (D'Occhio et al., 2001), which is responsible for increasing protein anabolism in animals.

Several studies have been carried out, in many countries, in order to evaluate the effectiveness of immunocastration on the productive efficiency and performance of animals, as well as on meat quality. However, when considered on their own, results do not always agree.

The objective of this work was to analyze the effects of immunocastration on the performance and carcass quality of steers in the finishing phase, compared with non-castration and surgical castration.

\section{Materials and Methods}

The meta-analysis was done using combined data from ten studies with records of 1,261 male bovines in the finishing phase and subjected to varying feeding systems in different countries (Table 1). The reviewed studies evaluated the effect of immunocastration with a specific vaccine to induce anti-GnRH antibody production, tackling parameters related to animal performance and carcass and meat quality.

The bibliographic research was done with specific search engines in the: Scientific Electronic Library Online (Scielo, 2015), Portal de Periódicos Capes/ MEC (Capes, 2015), ScienceDirect (Elsevier, 2015), and Web of Science (Clarivate Analytics, 2015). The keywords used in the research were: bovine or "feed cattle" or cal* or head; immunocast* or "against GnRH" or "castration methods"; and "average daily gain" or "carcass characteristic" or "animal welfare" or behavior*. The main criteria for including a work in the database were: group of immunocastrated steers as part of the trials; study performed between 2000 and May 2015, to avoid comparisons with excessivelyaged drug technologies; immunocastration carried out exclusively with a specific vaccine against GnRH; and daily weight gain, body weight characteristics, and carcass and meat quality as evaluated variables.

Specifically for animal performance characteristics, the criterion used for the inclusion of the studies was containing the initial weight, slaughter weight, and average daily weight gain (DWG) of the animals. For dry matter intake (DMI) and feed conversion, the criterion was describing these variables in a way that allowed calculating food efficiency, i.e., the ratio between the average DWG and daily DMI. According to Lovatto et al. (2007), when information for certain variables is lacking among the observed studies, multidimensional descriptive analytical resources are diminished in the analysis, requiring a one- or twodimensional approach.

For carcass and meat traits, a determinant condition for the inclusion of studies in the database was using standardization methods and evaluation equipment. In these studies, weight was measured immediately after slaughter and hot carcass yield was also calculated. The $\mathrm{pH}$ in the longissimus dorsi muscle was determined 24 hours after slaughter, at the twelfth rib of each animal, using a digital potentiometer. A sample corresponding to the $\mathrm{HH}$ section was taken from the right side of half carcass, to obtain the loin eye area (LEA) and to verify subcutaneous fat depth (SFD), coloring, and marbling. To determine LEA and SFD, the contour of the exposed longissimus dorsi muscle and the height of the fat covering this muscle were measured, respectively. Marbling was assessed by a subjective scoring scale, 
ranging from 1 to 18 . The color of the meat was evaluated by the Cielab system, using the CR-400 chroma meter (Konica Minolta Optics, Inc., Osaka, Japan); it should be noted that subjective evaluations of coloring were removed from the database. The losses of liquids during thawing and cooking were calculated according to Müller (1987), whereas shear force was determined using the Warner-Bratzler shear machine (G-R Manufacturing Inc., Trussville, AL, USA).

Each study of the database was designated as a random effect in the statistical model used, as suggested by St-Pierre (2007). The data compiled in the metaanalysis were subjected to Levene's test to verify the equality of variances. After this step, data normality was evaluated using the Kolmogorov-Smirnov test. Since DMI did not have a normal distribution, it was transformed with the DMI**4 function. The data were also subjected to the analysis of variance, at $5 \%$ probability, using the Mixed procedure of the SAS, version 9.2, statistical package (SAS Institute Inc., Cary, NC, USA). Means were compared by Student's t-test, at $5 \%$ probability. The best covariance structure was chosen using Akaike's information criterion (AIC). The following statistical model was adopted for the analysis of variance: , where $\mathrm{Y}_{\mathrm{ijk}}$ represents the dependent variables; $\mu$ is the mean of all observations; $T_{i}$ is the fixed effect of the $i^{\text {th }}$ castration condition; $E_{j}$ is the random effect of the $\mathrm{j}^{\text {th }}$ study; $\mathrm{R}_{\mathrm{k}}\left(\mathrm{T}_{\mathrm{i}}\right)$ is the $\mathrm{k}^{\text {th }}$ replicate effect, within the $\mathrm{i}^{\text {th }}$ treatment; and $\mathrm{e}_{\mathrm{ijk}}$ is the residual random effect associated with observation $\mathrm{Y}_{\mathrm{ijk}}$.

The variables DWG and SFD were further analyzed using a forest plot. Initially, a funnel plot was used to assess whether there was a publication bias in the metaanalysis. Since all the works included in the database had to necessarily evaluate immunocastration, steers subjected to this procedure were chosen as the control group, while the non-castrated and surgically-castrated ones formed the other two groups considered in the comparison. The data organized in each work, such as number of events, means, and standard deviations, were arranged in Microsoft Excel spread sheets and analyzed with the R, version 3.3.2, statistical software, using the Meta function of the MetaCon package (Schwarzer, 2007). Then, plots were built using the forest function. It should be highlighted that one of the works was removed from this analysis for not containing dispersion information and that there were comparative groups within one same study; these studies were called $\mathrm{a}$ and $\mathrm{b}$ in the plot description. The heterogeneity of the results between the experiments was measured using the $\mathrm{I}^{2}$ statistic (Higgins et al., 2003), which quantifies the impact of heterogeneity on the meta-analysis, with a mathematical criterion

Table 1. Description of the studies included in the database for conducting the meta-analysis.

\begin{tabular}{|c|c|c|c|c|c|c|}
\hline Study & Publication & Country & $\begin{array}{c}\text { Number of male } \\
\text { bovines }\end{array}$ & Food system & Breed & Treatment \\
\hline 1 & Cook et al. (2000) & Canada & 58 & Confinement & Cross breeds & Immunocastrated and non-castrated \\
\hline 2 & Andreo et al. (2013) & Brazil & 40 & Confinement & Nellore & Immunocastrated and non-castrated \\
\hline 3 & $\begin{array}{c}\text { Brigida (2014) and Antonello } \\
\text { (2015) }\end{array}$ & Brazil & 48 & Confinement & Nellore & Immunocastrated and non-castrated \\
\hline 4 & Machado (2015) & Brazil & 48 & $\begin{array}{c}\text { Pasture }+ \\
\text { supplement }\end{array}$ & Aberdeen Angus & Immunocastrated and non-castrated \\
\hline 5 & Freitas et al. (2015) & Brazil & 39 & Confinement & Cross breeds & $\begin{array}{l}\text { Immuno- and surgically castrated }+ \\
\text { non-castrated }\end{array}$ \\
\hline 6 & $\begin{array}{l}\text { Amatayakul-Chantler et al. } \\
\text { (2012) }\end{array}$ & Mexico & 800 & Confinement & Cross breeds & Immunocastrated and non-castrated \\
\hline 7 & Jannet et al. (2012) & Switzerland & 44 & - & Dutch & Immunocastrated and non-castrated \\
\hline 8 & Moreira (2013) & Brazil & 30 & $\begin{array}{c}\text { Pasture + } \\
\text { supplement }\end{array}$ & Cross breeds & $\begin{array}{c}\text { Immuno- and surgically castrated }+ \\
\text { non-castrated }\end{array}$ \\
\hline 9 & Miguel et al. (2014) & Brazil & 59 & Confinement & $\begin{array}{l}\text { Cross breeds and } \\
\text { Nellore }\end{array}$ & Immunocastrated and non-castrated \\
\hline 10 & $\begin{array}{l}\text { Amatayakul-Chantler et al. } \\
\text { (2013) }\end{array}$ & Brazil & 95 & Pasture & Nellore & Immunocastrated and non-castrated \\
\hline Total & - & - & 1,261 & - & - & - \\
\hline
\end{tabular}


independent of the number of studies and of the metric effect of each treatment; the choice for a fixed or random model was dependent on this heterogeneity.

\section{Results and Discussion}

The initial weight of the animals was similar between treatments (Table 2), showing the reliability of the results obtained after data compilation. However, the body weight of steers subjected to different castration conditions differed significantly at the time of slaughter, being greater for non-castrated animals, followed by immunocastrated and surgically-castrated ones.

Higher slaughter weights in non-castrated animals are a reflection of their greater development, compared with the castrated ones (Bretschneider, 2005). Castration reduces animal growth due to its adverse effect on androgenic anabolic hormones, besides causing stress, which can last up to 35 days (Coetzee, 2011). The results evaluated in the present study are in alignment with those of Vaz et al. (2014), who concluded that non-castrated mongrel males had a higher slaughter weight $(425.5 \pm 11.5 \mathrm{~kg})$ than those castrated by several methods $(392.13 \pm 12.1 \mathrm{~kg})$. Moreira et al. (2015) analyzed the same castration conditions as those of the present study and also found that non-castrated steers had superior slaughter weight; however, these authors did not observe differences between surgically- and immunocastrated animals.

The DWG of non-castrated animals was superior $(\mathrm{p}=0.0011)$ to those of the immunocastrated and surgically-castrated ones, which did not differ from each other. This result was confirmed by analyzing the forest plot (Figure 1), where an increase of $160 \mathrm{~g}$ per day was observed in the DWG of non-castrated steers, compared with immunocastrated animals. The groups of immunocastrated and surgically-castrated steers did not differ, since the diamond in the plot representing the meta-analysis touches the central axis, which refers to a relative risk $=1$. The random effect chosen in the construction of the meta-analysis took into account data on the heterogeneity between experiments, which was represented by $\mathrm{I}^{2}$. It should be pointed out that the meta-analysis showed a good weight distribution of each study, justifying the choice of the used model.

The superior performance of non-castrated steers is explained by the greater influence of male hormones, which aid in superior muscular development. According to Rodriguez et al. (2014), these animals gain weight faster by converting food into lean meat more efficiently than the castrated ones. In the latter, testosterone inhibition or testicle removal reduces or ceases testosterone production (Janett et al., 2012b), which affects the destination and use of ingested nutrients and weight gain (Oliver et al., 2003). In a study in Canada, Marti et al. (2015) hypothesized that the lower weight gain for surgically-castrated animals, followed by immunocastrated and non-castrated ones, was due to the pain inflicted by the surgery, which caused a reduction in food consumption and a redirection of nutrients towards the healing of the injured tissue.

Table 2. Means \pm standard error and significance of the treatments for performance variables of non-castrated, immunocastrated, and castrated steers ${ }^{(1)}$.

\begin{tabular}{|c|c|c|c|c|c|}
\hline Variable & Number & Non-castrated & Immunocastrated & Castrated & $\mathrm{p}$-value \\
\hline Initial weight $(\mathrm{kg})$ & 1,261 & $351.79 \pm 26.04$ & $348.44 \pm 25.99$ & $346.19 \pm 26.15$ & 0.5239 \\
\hline Slaughter weight (kg) & 1,261 & $505.88 \pm 0.86 \mathrm{a}$ & $484.89 \pm 20.69 b$ & $467.51 \pm 21.21 \mathrm{c}$ & 0.0009 \\
\hline Daily weight gain (kg per day) & 1,261 & $1.19 \pm 0.15 \mathrm{a}$ & $1.02 \pm 0.15 \mathrm{~b}$ & $0.93 \pm 0.15 b$ & 0.0011 \\
\hline Dry matter intake (kg per day) & 964 & $9.85 \pm 0.72$ & $9.64 \pm 0.72$ & $9.48 \pm 0.73$ & 0.9879 \\
\hline Feed conversion $\left(\mathrm{kg} \mathrm{kg}^{-1}\right)$ & 964 & $7.04 \pm 0.34$ & $7.67 \pm 0.34$ & $8.92 \pm 0.53$ & 0.0658 \\
\hline Feed efficiency $\left(\mathrm{kg} \mathrm{kg}^{1}\right)$ & 964 & $148.40 \pm 5.73 \mathrm{a}$ & $127.90 \pm 5.73 b$ & $119.80 \pm 6.54 b$ & 0.0004 \\
\hline Hot carcass weight $(\mathrm{kg})$ & 1,178 & $291.56 \pm 15.24 \mathrm{a}$ & $273.76 \pm 14.01 \mathrm{~b}$ & $263.90 \pm 15.40 \mathrm{c}$ & 0.0006 \\
\hline Hot carcass yield (\%) & 1,178 & $56.46 \pm 1.31$ & $55.88 \pm 1.30$ & $55.60 \pm 1.32$ & 0.1239 \\
\hline Loin eye area $\left(\mathrm{cm}^{2}\right)$ & 1,217 & $77.58 \pm 3.18 \mathrm{a}$ & $74.42 \pm 3.12 b$ & $70.98 \pm 3.26 \mathrm{c}$ & 0.077 \\
\hline Subcutaneous fat depth (mm) & 1,217 & $3.62 \pm 0.57 \mathrm{~b}$ & $4.28 \pm 0.55 \mathrm{ab}$ & $4.75 \pm 0.59 \mathrm{a}$ & 0.444 \\
\hline
\end{tabular}

${ }^{(1)}$ Means followed by equal letters, in the rows, do not differ by Student's t-test, at 5\% probability. 
Castration, however, did not influence DMI, which reflected in similar feed conversion, although the latter showed a reduction trend for non-castrated animals $(p=0.0658)$. Regarding feed efficiency, significant differences were observed between castration conditions, with higher values for noncastrated animals than for surgically-castrated and immunocastrated ones. This superior feed efficiency is related to the muscle expressiveness of non-castrated animals and to the lower energy demand for their growth, as previously discussed for slaughter weight and DWG. Moletta et al. (2014) pointed out that noncastrated animals use more nitrogen than castrated ones, with increased protein synthesis due to the influence of testosterone.

Hot carcass weight also differed significantly, being higher, intermediate, and lower $(\mathrm{p}=0.0006)$, respectively, for non-castrated, immunocastrated, and surgically-castrated steers. According to Pacheco et al. (2013), carcass weight is one of the most important characteristics for the producer, being directly related to their income. It should be noted that the values found for hot carcass weight reflect slaughter weight, as these characteristics have a high correlation. McCurdy et al. (2010) reported that the increase in slaughter weight improves both hot carcass weight and yield. Hot carcass yield, however, did not differ between noncastrated and castrated animals.

Significant differences were observed for LEA, which was greater for non-castrated animals, followed by immunocastrated and surgically-castrated ones. This is due to the greater body development of non-castrated steers, as evidenced by their greater slaughter and hot carcass weights, as well as by their lower amount of subcutaneous fat. The anabolic effect of testosterone is, once more, responsible for favoring the increase in protein deposition, at the expense of fat, in the animal carcass. Zhou et al. (2011) evaluated LEA in castrated and non-castrated Simmental steers finished in confinement, and also reported higher values for non-castrated animals. However, Pérez-Linares et al. (2017) found similar LEA when comparing non-castrated and immunocastrated steers, which is partly in alignment with the results gathered in the present study, where LEA was intermediate for immunocastrated animals. The better performance of these steers, compared with the surgicallycastrated ones, may be related to the time it takes for immunocastration to become effective, which occurs approximately two weeks after the second vaccination,

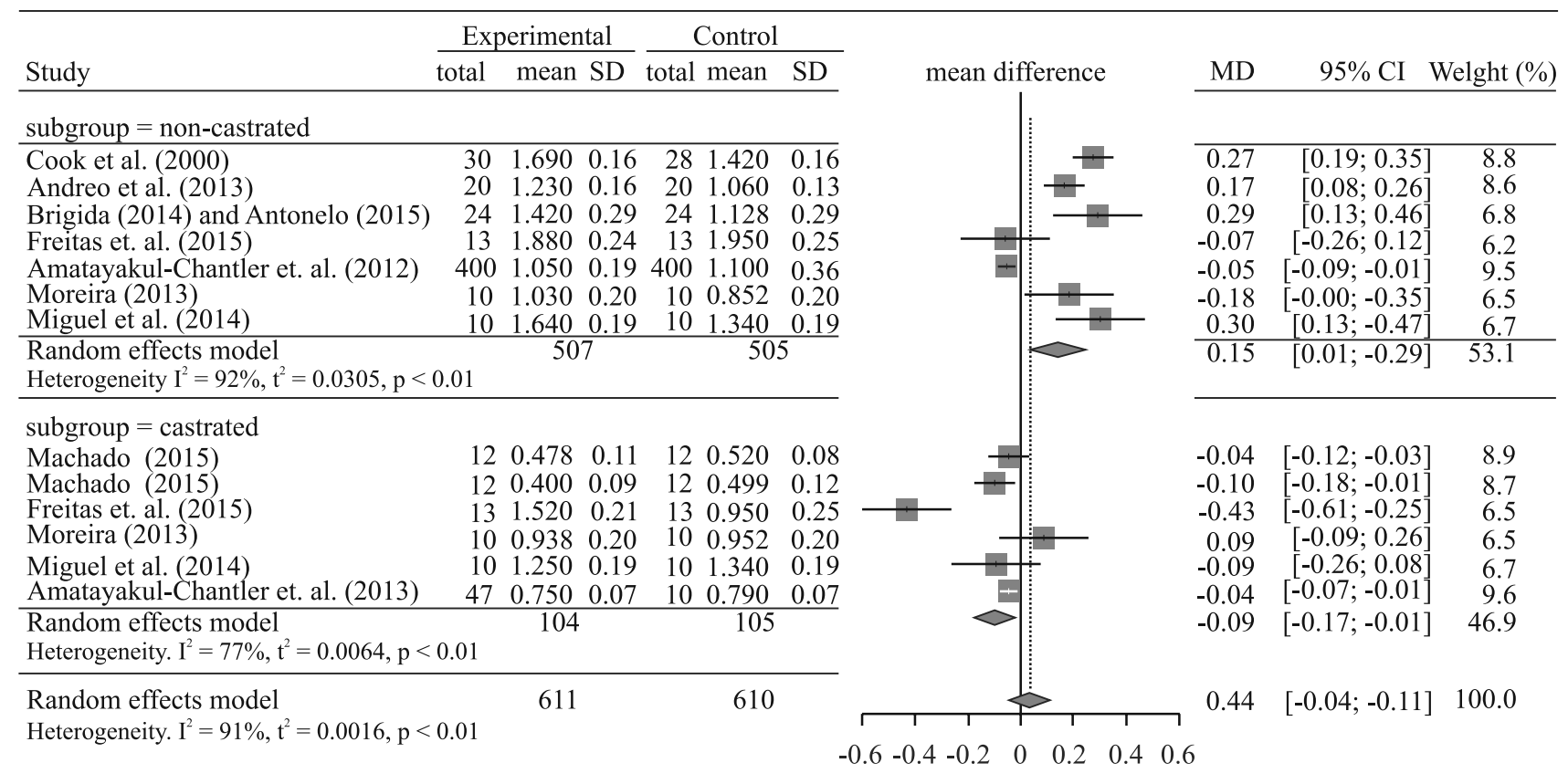

Figure 1. Forest plot for daily weight gain of steers subjected to different castration treatments. SD, standard deviation; MD, mean deviation; and CI, confidence interval. 
delaying the reduced efficiency in muscle deposition caused by the treatment. This might be possible, especially in the cases of confined animals, due to the shorter time in the finishing phase; in this metaanalysis, the confinement system represented $60 \%$ of the works that made up the database.

As observed for the other variables, immunocastrated steers also showed intermediate SFD, compared with the other groups. The forest plot indicated a similar result (Figure 2), but with a tendency of immunocastrated steers presenting SFD $0.79 \mathrm{~mm}$ greater than that of non-castrated animals, but similar to that of the surgically-castrated group. This corroborates the work of Turini et al. (2015), who found that the deposition of adipose tissue is delayed in the meat of non-castrated animals, as they complete their muscle development later than the castrated ones.

According to Medeiros et al. (2010), muscle and fat deposition rates have a direct effect on food efficiency, since gross efficiency (kilogram of feed per kilogram of body weight) is lower for fat deposition than for muscle tissue development. This fact explains why non-castrated animals showed higher feed efficiency, greater LEA, and lower SFD (Table 2).

The final $\mathrm{pH}$ of meat did not differ between treatments (Table 3), being close to the values of 5.4-5.8 considered as ideal for 24-hour post-mortem beef according to Mach et al. (2008). Silva et al. (2014) observed that the 24-hour post-mortem $\mathrm{pH}$ value was statistically lower for castrated (5.51) than for noncastrated steers (5.62), and the authors correlated this result with the greater accumulation of lactate in the muscle of castrated animals. The data evaluated in the present study, however, agree with those of Pérez-Linares et al. (2017), who verified similar $\mathrm{pH}$ values for longissimus dorsi in non-castrated and immunocastrated steers.

The color values of $a^{*}$ (highest red intensity) and $b^{*}$ (highest yellow intensity) differed between treatments, with non-castrated steers presenting the lowest values. Silva et al. (2014) also reported higher $a^{*}$ and $b^{*}$ values for castrated steers. Therefore, the flesh color of steers subjected to castration, be it surgical or immunological, showed more favorable attributes to commercialization, as this is the first characteristic

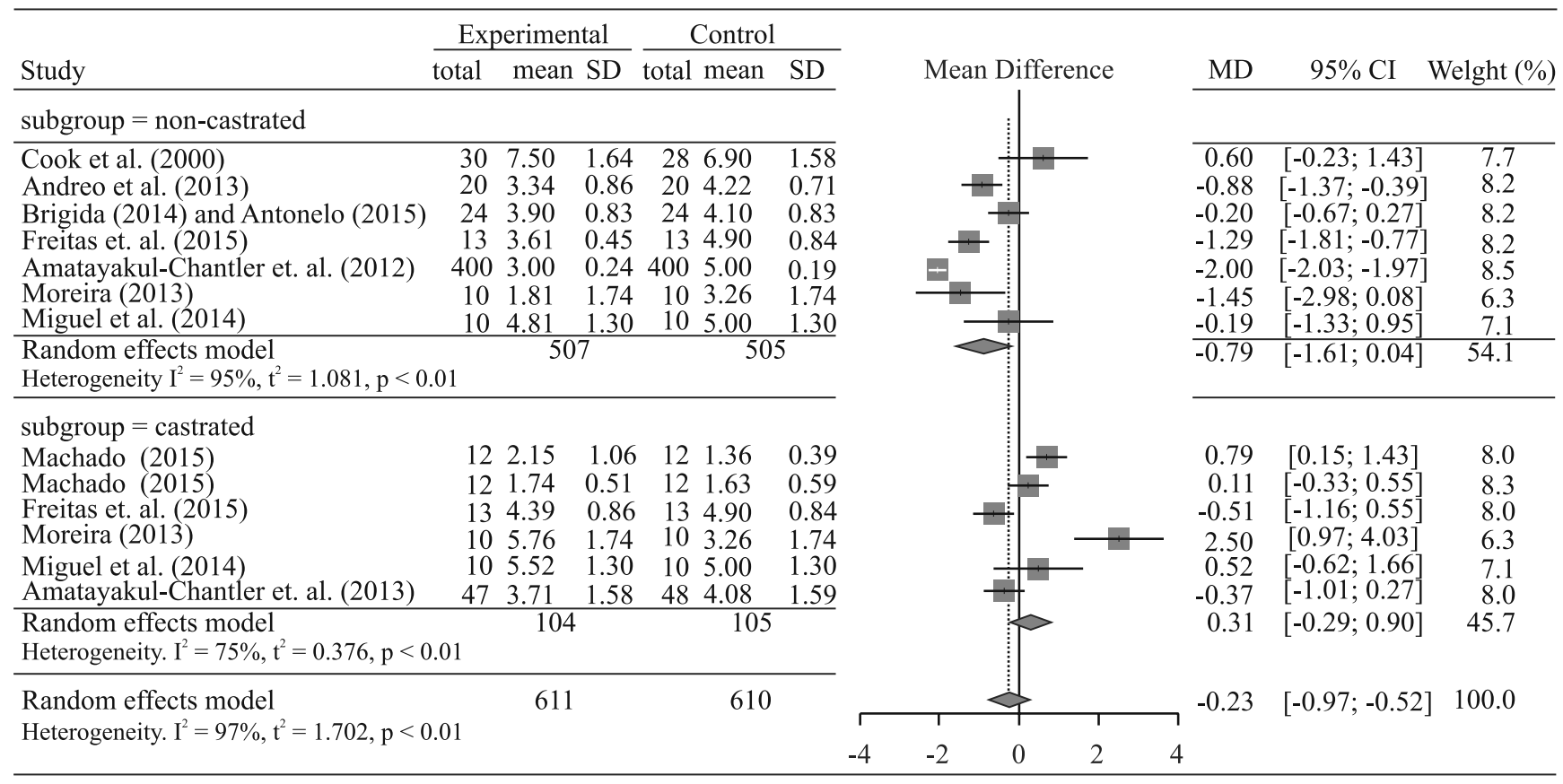

Figure 2. Forest plot for subcutaneous fat depth of steers subjected to different castration treatments. SD, standard deviation; MD, mean deviation; and CI, confidence interval. 
Table 3. Means \pm standard error and significance of the treatments for meat quality variables of non-castrated, immuncastrated, and castrated steers ${ }^{(1)}$.

\begin{tabular}{|c|c|c|c|c|c|}
\hline Variable & Number & Non-castrated & Immunocastrated & Castrated & p-value \\
\hline Carcass pH & 1,120 & $5.82 \pm 0.08$ & $5.67 \pm 0.06$ & $5.69 \pm 0.08$ & 0.3318 \\
\hline$a^{*}$ value & 1024 & $14.46 \pm 1.79 \mathrm{~b}$ & $16.25 \pm 1.77 \mathrm{a}$ & $16.40 \pm 1.82 \mathrm{a}$ & 0.0431 \\
\hline$b^{*}$ value & 1,024 & $6.37 \pm 0.82 b$ & $7.48 \pm 0.80 \mathrm{a}$ & $8.17 \pm 0.84 \mathrm{a}$ & 0.0204 \\
\hline $\mathrm{L}$ value & 1,024 & $34.26 \pm 1.50$ & $35.45 \pm 1.44$ & $36.39 \pm 1.58$ & 0.2874 \\
\hline Marbling $^{(2)}$ & 127 & $2.13 \pm 0.81$ & $2.48 \pm 0.80$ & $2.83 \pm 0.81$ & 0.1118 \\
\hline Shear force $(\mathrm{kgF} \mathrm{cm})$ & 1,130 & $7.17 \pm 0.66$ & $6.71 \pm 0.62$ & $7.10 \pm 0.68$ & 0.5593 \\
\hline Loss during thawing $(\%)$ & 88 & $7.57 \pm 3.16$ & $10.58 \pm 3.13$ & $11.70 \pm 3.15$ & 0.0586 \\
\hline Loss during cooking (\%) & 242 & $23.77 \pm 1.84$ & $26.37 \pm 1.66$ & $26.14 \pm 1.71$ & 0.1603 \\
\hline
\end{tabular}

${ }^{(1)}$ Means followed by equal letters, in the rows, do not differ by Student's t-test, at $5 \%$ probability. ${ }^{(2)}$ Determined by subjective scoring, using a scale from 1 to 18 points.

observed and considered for purchase by the consumer in the supermarket or butcher shop.

Meat coloration is also affected by low SFD, which makes it darker, since there is no fat to protect the carcass during cooling and reduce $\mathrm{pH}$ during rigor mortis. The lower fat depth in non-castrated animals (Table 2) could be directly related to the coloration of their meat, rendering it less desirable.

The marbling and shear force values were similar between treatments. The marbling score was below the desired values for all treatments. The production system and especially the time of finishing of the slaughtered cattle, in the studies compiled for the meta-analysis, may have led to this result. Another aspect that should be considered is the genetic composition of the steers used in the studies - $40 \%$ Zebu, $40 \%$ cross breed, and only $20 \%$ European. European animals notably present a higher degree of marbling of meat. Huxsool et al. (1998) did not observe a significant difference in the degree of marbling between animals subjected to surgical and anti-GnRH immunization castrations.

The losses during thawing and cooking were also evaluated due to their importance in preparing meat cuts for consumption, affecting mainly juiciness. However, none of these variables differed statistically between the analyzed groups. It should be noted, though, that thawing loss presented a tendency to change among treatments $(\mathrm{p}=0.0586)$ : meat from non-castrated steers retained more water than that from castrated animals. Similar results were reported by Moletta et al. (2014), who found thawing losses of $4.29 \%$ for non-castrated steers and of $6.88 \%$ for the castrated ones. This result is probably associated with the higher finishing degree of non-castrated animals, which prevents greater losses of liquid during cooling (Moletta et al., 2014). In the present study, this hypothesis was confirmed, since the steers with greater depths of cover fat tended to present greater losses of liquids during thawing.

\section{Conclusions}

1. Non-castrated steers have greater daily weight gain, feed efficiency, slaughter weight, hot carcass weight, and loin eye area than castrated animals.

2. Immunocastrated steers present greater slaughter weight, hot carcass weight, and loin eye area than surgically-castrated animals.

3. The meat of steers subjected to surgical or immunological castration presents greater subcutaneous fat depth and better coloring, but greater losses during thawing.

\section{References}

AMATAYAKUL-CHANTLER, S.; HOE, F.; JACKSON, J.A.; ROCA, R.O.; STEGNER, J.E.; KING, V.; HOWARD, R.; LOPEZ, E.; WALKER, J. Effects on performance and carcass and meat quality attributes following immunocastration with the gonadotropin releasing factor vaccine Bopriva or surgical castration of Bos indicus bulls raised on pasture in Brazil. Meat Science, v.95, p.78-84, 2013. DOI: 10.1016/j.meatsci.2013.04.008.

AMATAYAKUL-CHANTLER, S.; JACKSON, J.A.; STEGNER, J.; KING, V.; RUBIO, L.M.S.; HOWARD, R.; LOPEZ, E.; WALKER, J. Immunocastration of Bos indicus x Brown Swiss bulls in feedlot with gonadotropin-releasing hormone vaccine Bopriva provides improved performance and meat quality. Journal of Animal Science, v.90, p.3718-3728, 2012. DOI: 10.2527/jas.2011-4826. 
ANDREO, N.; BRIDI, A.M.; TARSITANO, M.A.; PERES, L.M.; BARBON, A.P.A. da C.; ANDRADE, E.L. de; PROHMANN, P.E.F. Influência da imunocastração (Bopriva ${ }^{\circledR}$ ) no ganho de peso, características de carcaça e qualidade da carne de bovinos Nelore. Semina: Ciências Agrárias, v.34, p.4121-4132, 2013. Suplemento 2. DOI: 10.5433/1679-0359.2013v34n6Supl2p4121.

ANTONELO, D.S. Efeitos da imunocastração e de betaagonistas adrenérgicos sobre o desempenho, perfil sanguíneo, comportamento ingestivo e características de carcaça de bovinos Nelore confinados. 2015. 74p. Dissertação (Mestrado) - Universidade de São Paulo, Pirassununga. DOI: 10.11606/D.74.2015.tde-28042015-095048.

BRETSCHNEIDER, G. Effects of age and method of castration on performance and stress response of beef male cattle: a review. Livestock Production Science, v.97, p.89-100, 2005. DOI: 10.1016/j.livprodsci.2005.04.006.

BRIGIDA, D.J. Características de carcaça e rendimento de cortes comerciais de bovinos Nelore confinados, imunocastrados e suplementados com beta-agonistas. 2014. 42p. Dissertação (Mestrado) - Universidade de São Paulo, Pirassununga. DOI: 10.11606/D.74.2014.tde-25092014-094753.

CAPES. Coordenação de Aperfeiçoamento de Pessoal de Nível Superior. Portal de Periódicos Capes/Mec. Available at: $<$ http:// www.periodicos.capes.gov.br>. Accessed on: Aug. 192015.

CLARIVATE ANALYTICS. Web of Science. Available at: https://clarivate.com/products/web-of-science/. Accessed on: Aug. 192015.

COETZEE, J.F. A review of pain assessment techniques and pharmacological approaches to pain relief after bovine castration: practical implications for cattle production within the United States. Applied Animal Behavior Science, v.135, p.192-213, 2011. DOI: 10.1016/j.applanim.2011.10.016.

COETZEE, J.F.; NUTSCH, A.L.; BARBUR, L.A.; BRADBURN, R.M. A survey of castration methods and associated livestock management practices performed by bovine veterinarians in the United States. BMC Veterinary Research, v.6, p.1-19, 2010. DOI: 10.1186/1746-6148-6-12.

COOK, R.B.; POPP, J.D.; KASTELIC, J.P.; ROBBINS, S.; HARLAND, R. The effects of active immunization against $\mathrm{GnRH}$ on testicular development, feedlot performance, and carcass characteristics of beef bulls. Journal of Animal Science, v.78, p.2778-2783, 2000. DOI: 10.2527/2000.78112778x.

D’OCCHIO, M.J.; ASPDEN, W.J.; TRIGG, T.E. Sustained testicular atrophy in bulls actively immunized against GnRH: potential to control carcase characteristics. Animal Reproduction Science, v.66, p.47-58, 2001. DOI: 10.1016/S0378-4320(01) 00091-4.

ELSEVIER. Science Direct. Available at: http://www. sciencedirect.com. Accessed on: Aug. 222015.

FREITAS, A.K. de; RESTLE, J.; PACHECO, P.S.; PADUA, J.T.; LAGE, M.E.; MIYAGI, E.S.; SILVA, G.F.R. da. Características de carcaças de bovinos Nelore inteiros vs castrados em duas idades, terminados em confinamento. Revista Brasileira de Zootecnia, v.37, p.1055-1062, 2008. DOI: 10.1590/S151635982008000600016 .
FREITAS, V.M. de; LEÃO, K.M.; ARAUJO NETO, F.R. de; MARQUES, T.C.; FERREIRA, R.M.; GARCIA, L.L.F.; OLIVEIRA, E.B. de. Effects of surgical castration, immunocastration and homeopathy on the performance, carcass characteristics and behaviour of feedlot-finished crossbred bulls. Semina: Ciências Agrárias, v.36, p.1725-1734, 2015. DOI: 10.5433/1679-0359.2015v36n3p1725.

GRANDIN, T. Animal welfare and society concerns finding the missing link. Meat Science, v.98, p.461-469, 2014. DOI: 10.1016/j. meatsci.2014.05.011.

HIGGINS, J.P.T.; THOMPSON, S.G.; DEEKS, J.J.; ALTMAN, D.G. Measuring inconsistency in meta-analyses. BMJ, v.327, p.557-560, 2003. DOI: 10.1136/bmj.327.7414.557.

HUXSOOL, C.C.; PRICE, E.O.; ADAMS, T.E. Testis function, carcass traits, and aggressive behavior of beef bulls actively immunized against gonadotropin-releasing hormone. Journal of Animal Science, v.76, p.1760-1766, 1998. DOI: 10.2527/1998.7671760x.

JANETT, F.; GERIG, T.; TSCHUOR, A.C.; AMATAYAKULCHANTLER, S.; WALKER, J.; HOWARD, R.; BOLLWEIN, H.; THUN, R. Vaccination against gonadotropin-releasing factor (GnRF) with Bopriva significantly decreases testicular development, serum testosterone levels and physical activity in pubertal bulls. Theriogenology, v.78, p.182-188, 2012a. DOI: 10.1016/j.theriogenology.2012.01.035.

JANETT, F.; GERIG, T.; TSCHUOR, A.C.; AMATAYAKULCHANTLER, S.; WALKER, J.; HOWARD, R.; PIECHOTTA, M.; BOLLWEIN, H.; HARTNACK, S.; THUN, R. Effect of vaccination against gonadotropin-releasing factor $(\mathrm{GnRF})$ with Bopriva ${ }^{\circledR}$ in the prepubertal bull calf. Animal Reproduction Science, v.131, p.72-80, 2012b. DOI: 10.1016/j.anireprosci.2012.02.012.

LOVATTO, P.A.; LEHNEN, C.R.; ANDRETTA, I.; CARVALHO, A.D.; HAUSCHILD, L. Meta-análise em pesquisas científicas - enfoque em metodologias. Revista Brasileira de Zootecnia, v.36, p.285-294, 2007. Suplemento especial. DOI: 10.1590/S151635982007001000026 .

MACH, N.; BACH, A.; VELARDE, A.; DEVANT, M. Association between animal, transportation, slaughterhouse practices, and meat $\mathrm{pH}$ in beef. Meat Science, v.78, p.232-238, 2008. DOI: 10.1016/j.meatsci.2007.06.021.

MACHADO, D. Uso da imunocastração como alternativa à castração cirúrgica na produção de novilhos para abate. 2015. 99p. Dissertação (Mestrado) - Universidade Federal de Santa Maria, Santa Maria.

MARTI, S.; DEVANT, M.; AMATAYAKUL-CHANTLER, S.; JACKSON, J.A.; LOPEZ, E.; JANZEN, E.D.; SCHWARTZKOPFGENSWEIN, K.S. Effect of anti-gonadotropin-releasing factor vaccine and band castration on indicators of welfare in beef cattle. Journal of Animal Science, v.93, p.1581-1591, 2015. DOI: 10.2527/jas.2014-8346.

MCCURDY, M.P.; KREHBIEL, C.R.; HORN, G.W.; LANCASTER, P.A.; WAGNER, J.J. Effects of winter growing program on visceral organ mass, composition, and oxygen consumption of beef steers during growing and finishing. Journal 
of Animal Science, v.88, p.1554-1563, 2010. DOI: 10.2527/ jas.2009-2415.

MEDEIROS, S.R. de; ALMEIDA, R.; LANNA, D.P.D. Manejo da recria: eficiência do crescimento da desmama à terminação. In: PIRES, A.V. (Ed.). Bovinocultura de corte. Piracicaba: Fealq, 2010. v.1, p.159-170.

MIGUEL, G.Z.; FARIA, M.H.; ROÇA, R.O.; SANTOS, C.T.; SUMAN, S.P.; FAITARONE, A.B.G.; DELBEM, N.L.C.; GIRAO, L.V.C.; HOMEM, J.M.; BARBOSA, E.K.; SU, L.S.; RESENDE, F.D.; SIQUEIRA, G.R.; MOREIRA, A.D.; SAVIAN, T.V. Immunocastration improves carcass traits and beef color attributes in Nellore and Nellore x Aberdeen Angus crossbred animals finished in feedlot. Meat Science, v.96, p.884-891, 2014. DOI: 10.1016/j.meatsci.2013.08.030.

MOLETTA, J.L.; PRADO, I.N. do; FUGITA, C.A.; EIRAS, C.E.; CARVALHO, C.B.; PEROTTO, D. Características da carcaça e da carne de bovinos não-castrados ou castrados terminados em confinamento e alimentados com três níveis de concentrado. Semina: Ciências Agrárias, v.35, p.1035-1050, 2014. DOI: 10.5433/1679-0359.2014v35n2p1035.

MOREIRA, A.D. Métodos de castração de machos Aberdeen Angus x Nelore terminados em pastagem. 2013. 72p. Dissertação (Mestrado) - Universidade Estadual Paulista, Jaboticabal.

MOREIRA, P.S.A.; LOURENÇO, F.J.; LIMA, C. da C.; FARIA, F.F.; EL FARRA, A.; ROMERO, N.B. Desempenho produtivo e características de carcaça de bovinos Nelore submetidos a diferentes métodos de castração. Revista Brasileira de Ciências Agrárias, v.10, p.570-575, 2015. DOI: 10.5039/agraria.v10i4a5150.

MÜLLER, L. Normas para avaliação de carcaças e concurso de carcaça de novilhos. 2.ed. Santa Maria: Universidade Federal de Santa Maria, 1987. 31p.

OLIVER, W.T.; MCCAULEY, I.; HARRELL, R.J.; SUSTER, D.; KERTON, D.J.; DUNSHEA, F.R. A gonadotropin-releasing factor vaccine (Improvac) and porcine somatotropin have synergistic and additive effects on growth performance in group-housed boars and gilts. Journal of Animal Science, v.81, p.1959-1966, 2003. DOI: $10.2527 / 2003.8181959 x$.

PACHECO, P.S.; RESTLE, J.; MISSIO, R.L.; MENEZES, L.F.G.; ROSA, J.R.P.; KUSS, F.; ALVES FILHO, D.C.; NEIVA, J.N.M.; DONICHT, P.A.M.M. Características da carcaça e do corpo vazio de bovinos Charolês de diferentes categorias abatidos com similar grau de acabamento. Arquivo Brasileiro de Medicina Veterinária e Zootecnia, v.65, p.281-288, 2013. DOI: 10.1590/ S0102-09352013000100040.
PÉREZ-LINARES, C.; BOLADO-SARABIA, L.; FIGUEROASAAVEDRA, F.; BARRERAS-SERRANO, A.; SÁNCHEZLÓPEZ, E.; TAMAYO-SOSA, A.R.; GODINA, A.A.; RÍOSRINCÓN, F.; GARCÍA, L.A.; GALLEGOS, E. Effect of immunocastration with Bopriva on carcass characteristics and meat quality of feedlot Holstein bulls. Meat Science, v.123, p.4559, 2017. DOI: 10.1016/j.meatsci.2016.08.006.

PRICE, E.O.; ADAMS, T.E.; HUXSOLL, C.C.; BORGWARDT, R.E. Aggressive behavior is reduced in bulls actively immunized against gonadotropin-releasing hormone. Journal of Animal Science, v.81, p.411-415, 2003. DOI: $10.2527 / 2003.812411 x$.

RODRIGUEZ, J.; UNRUH, J.; VILLARREAL, M.; MURILLO, O.; ROJAS, S.; CAMACHO, J.; JAEGER, J.; REINHARDT, C. Carcass and meat quality characteristics of Brahman cross bulls and steers finished on tropical pastures in Costa Rica. Meat Science, v.96, p.1340-1344, 2014. DOI: $10.1016 /$ j.meatsci.2013.10.024.

SCHWARZER, G. meta: an R package for Meta-Analysis. R News, v.7, p.40-45, 2007.

SCIELO. Scientific Electronic Library Online. Available at: $<$ http://www.scielo.br>. Accessed on: Aug. 222015.

SILVA, B.; POLETI, M.D.; MONCAU, C.T.; ROSA, A.F.; SILVA, S. da L.; BALIEIRO, J.C. de C. Características endócrinas, metabólicas e indicadoras da qualidade da carne em bovinos Nelore castrados e não castrados. Ciência Rural, v.44, p.904-910, 2014. DOI: 10.1590/S010384782014005000003.

ST-PIERRE, N.R. Meta-analyses of experimental data in the animal sciences. Revista Brasileira de Zootecnia, v.36, p.343358, 2007. DOI: 10.1590/S1516-35982007001000031. Suplemento especial.

TURINI, T.; RIBEIRO, E.L. de A.; ALVES, S.J.; MIZUBUTI, I.Y.; SILVA, L. das D.F. da. Desempenho de bovinos inteiros e castrados em sistema intensivo de integração lavoura-pecuária. Semina: Ciências Agrárias, v.36, p.2339-2352, 2015. Suplemento 1. DOI: $10.5433 / 1679-0359.2015 v 36 n 3$ Supl1p2339.

VAZ, F.N.; RESTLE, J.; PÁDUA, J.T.; MORALES, D.C.S.P.; PACHECO, P.S.; MAYSONNAVE, G.S. Características de carcaça e da carne de bovinos mestiços não-castrados ou submetidos a diferentes métodos de castração. Ciência Animal Brasileira, v.15, p.428-436, 2014. DOI: 10.1590/1089-6891v15i426218.

ZHOU, Z.-K.; GAO, X.; LI, J.-Y.; CHEN, J.-B.; XU, S.-Z. Effect of castration on carcass quality and differential gene expression of longissimus muscle between steer and bull. Molecular Biology Reports, v.38, p.5307-5312, 2011. DOI: 10.1007/s11033-0110680-y.

$\overline{\text { Received on February 7, } 2017 \text { and accepted on October 27, } 2017}$

Pesq. agropec. bras., Brasília, v.53, n.8, p.961-969, Aug. 2018 DOI: $10.1590 / \mathrm{S} 0100-204 \mathrm{X} 2018000800011$ 